Brit. J. prev. soc. Med. (1965), 19, 192-197

\title{
TRADITION IN TRANSITION
}

\section{A HEALTH OPINION SURVEY IN IBADAN, NIGERIA}

\author{
BY \\ CATHERINE M. U. MACLEAN* \\ Ibadan, Nigeria
}

During the course of a cancer survey carried out in Ibadan, Nigeria, from 1960-63, the apparent low cancer incidence rates, particularly in the elderly, raised questions regarding the use being made of the available modern medical facilities by the population at risk. The fallacies inherent in any incidence survey of disease based solely upon hospital diagnosed cases are exaggerated in a developing country. Particularly was this likely to be the case in Ibadan, where the University College Hospital had been opened only in 1957. Although it was continually besieged by patients, nothing was known of its reputation in the eyes of the city's remaining inhabitants.

Ibadan is the administrative, commercial, and educational centre of the Western Region of Nigeria, but it still retains, both in its architectural and occupational structure, many of the features of the large Yoruba villages which are characteristic of this part of Nigeria (Lloyd, 1960). In 1962 Ibadan had a population of approximately 479,000 .

The city is extremely well off by African standards in respect of its medical services, since, in addition to the University College Hospital, which is staffed and equipped in a manner comparable to any teaching hospital in the Western hemisphere, it is also served by the Government general hospital of Adeoyo, a Government nursing home for senior civil servants, a Catholic mission hospital, and a number of private clinics run by general practitioners. In 1963 the total number of Ibadan hospital beds was 920 and there were 145 doctors in the town, a bed-patient ratio of $1: 540$ and a doctor : patient ratio of $1: 3,300$.

Attendance figures at the major hospitals indicated a high demand for the available services. During the period 1960 to 1963 , approximately 30,000 new Ibadan patients were attending University College Hospital per year, Adeoyo hospital received some 93,000 new Ibadan patients per year, the average

* M.R.C. Unit for Research on the Epidemiology of Mental Illness, Department of Psychological Medicine. University of Edinburgh. number of patients (mainly obstetric and paediatric cases) at the Catholic mission hospital being 32,500 per year.

Following a pilot survey among out-patients at University College Hospital, which had suggested that native methods of treatment were by no means discarded even by this highly-selected group, it was decided to carry out an attitude survey in the town.

There was at that time no suitable frame available from which to draw a random sample of inhabitants. Recourse was had to studying two separate groups who, it was hypothesized, might differ in their use of hospitals and local forms of treatment. A demarcated district, $E_{2}$, was chosen in the traditional area known as "Old Ibadan", and a senior member of each household in this area was to be questioned regard- : ing the family's habitual behaviour in the event of illness. At the same time Ibadan secondary school pupils were to be asked about the practices current in their families. These children came from the emerging Nigerian élite, who could appreciate and afford the benefits of a grammar school type education.

The population figure for district $E_{2}$ had been provisionally placed, following the abortive Nigerian Census of 1962, at 5,790. At the same time, a WHO tuberculosis survey team had estimated its population at 6,164 . An aerial survey map of the area which was obtained and enlarged revealed 528 roofed buildings. This map was subdivided, along the lines of paths or open spaces, into 21 segments, each containing some 25 dwellings. Each subsection was then personally surveyed with the object of determining landmarks to define the areas on the ground and these features were then marked upon the relevant map sections. This preliminary survey in the field also provided an opportunity for establishing good relations with the people of $E_{2}$ district. Many expressed interest in the mapping procedure and were told something of its purpose and of the forthcoming interviews. The impression was gained that most people would be happy to discuss matters of health and hospital provision. 
Interviewing was made the responsibility of 21 Yoruba students of sociology and economics from Ibadan University. They were carefully briefed beforehand in the purpose and conduct of the interviews and their advice was taken regarding the appropriate vernacular rendering of several of the questions. The male head of the household was to be sought as a respondent in the first instance but, in his absence, any responsible adult was to be questioned. The interviews took place at the time of the Moslem feast of Ramadhan, in early February, 1963.

A semi-structured form of questionnaire was employed, some of the answers requiring the respondent's own words whilst in other cases alternative possible replies were already listed. Preliminary demographic data on the informant's age, occupation, literacy, and position in the household were followed by a series of questions on the use of native medicines in general, their source and mode of preparation, and the identity of the family authority on medication. Next came specific questions regarding the treatment of convulsions in children and the recommended therapy for fever, jaundice, and smallpox. Informants were asked their opinion of what diseases hospitals could treat and which particular hospitals they or their families were in the habit of patronizing and for what reasons. At the same time information was obtained regarding their use of local healers, their familiarity with European-trained private practitioners, and their attitude to the faith healers of an Apostolic Church sect whose adherents in Ibadan are on the increase. Finally, they were asked whose permission, if any, was necessary before a mother decided to take her child to hospital.

Fourteen Ibadan secondary schools co-operated in the other section of the study. The one remaining secondary school, where repeated visits had failed to discover the Principal, had to be left out of the survey. The schools varied widely, not only in physical structure and amenities but also in their educational standards. They included the Government Grammar School for boys and other establishments either privately run or supported by a variety of religious organizations. Catholics, Anglicans, Methodists, Moslems, and African Separatist churches all invest in Nigerian higher education.

After initial contact with the head teachers and a brief explanation to the classes concerned, questionnaires were issued to those senior pupils whose parents were resident in Ibadan. There was a total of 282 pupils in this category. They were all allowed to remain anonymous and, after furnishing information on their parents, were asked personally to complete a shortened version of the schedule which had been used for the adults in $E_{2}$.

\section{RESULTS}

506 interviews were completed in $E_{2}$ district, 400 of the informants being men and 106 women. 58 per cent. of the men and 86 per cent. of the women in the group were illiterate, having had no formal schooling of any kind.

The majority of the men were artisans $(30.5$ per cent.), followed by farmers ( 22.5 per cent.) and traders (14.8 per cent.); among the remainder there were twelve native doctors ( 3 per cent.).

Of the women 90 per cent. were traders; only seven (6.6 per cent.) classed themselves purely as housewives, and one woman was a priestess.

By contrast, 52 per cent. of the school children's fathers had a profession, such as teacher, doctor, politician, pastor, lawyer, engineer, or held a highgrade secretarial or civil service post; only 10 per cent. of the fathers were artisans, $17 \cdot 7$ per cent. were traders or contractors, and 11.7 per cent. were farmers.

Among the mothers of the school children, 70 per cent. were traders. Those in unskilled occupations, or described simply as housewives, formed 12.4 per cent., and no occupation was stated in 9.6 per cent. But 17 per cent. of the mothers were teachers or nurses, or were engaged in some other occupation which had involved a specialized training after leaving school.

\section{Reported Use of Native Medicine}

Table I compares the reported use of native medicines by the two Ibadan groups.

TABLE I

REPORTED USE OF NATIVE MEDICINES IN E, DISTRICT AND IN SCHOOL CHILDREN'S FAMILIES

\begin{tabular}{|c|c|c|c|c|c|}
\hline \multirow{3}{*}{\multicolumn{2}{|c|}{$\begin{array}{l}\text { Use of } \\
\text { Native Medicines }\end{array}$}} & \multicolumn{4}{|c|}{ Type of Family } \\
\hline & & \multicolumn{2}{|c|}{ E, District } & \multicolumn{2}{|c|}{ School Children } \\
\hline & & \multirow{2}{*}{ 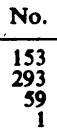 } & \multirow{2}{*}{ 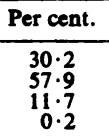 } & \multirow{2}{*}{$\begin{array}{r}\text { No. } \\
110 \\
166 \\
6 \\
0\end{array}$} & \multirow{2}{*}{$\begin{array}{c}\text { Per cent. } \\
39.0 \\
58.9 \\
2.1 \\
0.0\end{array}$} \\
\hline $\begin{array}{l}\text { Never .. } \\
\text { Sometimes } \\
\text { Always . . } \\
\text { No Reply }\end{array}$ & $\begin{array}{l}\cdots \\
\cdots \\
\cdots\end{array}$ & & & & \\
\hline Total & $\ldots$ & 506 & $100 \cdot 0$ & 282 & $100 \cdot 0$ \\
\hline
\end{tabular}

It will be noted that over 60 per cent. of both types of family, those of the educated elite and of the less privileged poor, "sometimes" had recourse to native treatments. 
Use of Native Remedies and Age.-When the reported employment of traditional methods was considered in relation to the age of the male informants in $E_{2}$ (Table II), it appeared that the use of native medicines increased significantly with age $\left(x^{2}=26.025 ;\right.$ d.f. $\left.4 ; \mathrm{P}<0.001\right)$.

TABLE II

USE OF NATIVE MEDICINES, OF 398* MALE INFORMANTS IN $E_{3}$, BY AGE

\begin{tabular}{|c|c|c|c|c|c|c|c|c|c|}
\hline \multirow{3}{*}{\multicolumn{2}{|c|}{$\begin{array}{l}\text { Use of } \\
\text { Native Medicines }\end{array}$}} & \multicolumn{8}{|c|}{ Age Group (yrs) } \\
\hline & & \multicolumn{2}{|c|}{$20-34$} & \multicolumn{2}{|c|}{$35-50$} & \multicolumn{2}{|c|}{$50+$} & \multicolumn{2}{|c|}{ All Ages } \\
\hline & & No. & $\begin{array}{c}\text { Per } \\
\text { cent. }\end{array}$ & No. & $\begin{array}{c}\text { Per } \\
\text { cent. }\end{array}$ & No. & $\begin{array}{l}\text { Per } \\
\text { cent. }\end{array}$ & No. & $\begin{array}{c}\text { Per } \\
\text { cent. }\end{array}$ \\
\hline $\begin{array}{l}\text { Always ... } \\
\text { Sometimes } \\
\text { Never .. }\end{array}$ & $\because$. & $\begin{array}{l}10 \\
64 \\
41\end{array}$ & $\begin{array}{r}8.7 \\
55.7 \\
35.7\end{array}$ & $\begin{array}{l}15 \\
99 \\
48\end{array}$ & $\begin{array}{r}9 \cdot 3 \\
61 \cdot 1 \\
29 \cdot 6\end{array}$ & $\begin{array}{l}26 \\
70 \\
25\end{array}$ & $\begin{array}{l}21.5 \\
57.9 \\
20.7\end{array}$ & $\begin{array}{r}51 \\
233 \\
114 \\
\end{array}$ & $\begin{array}{l}12.8 \\
58.5 \\
28.6\end{array}$ \\
\hline Total & .. & 115 & $\overline{100 \cdot 0}$ & 162 & $\overline{100 \cdot 0}$ & 121 & $100 \cdot 0$ & 398 & $100 \cdot 0$ \\
\hline
\end{tabular}

*In two cases the age was not stated.

Personal Knowledge of Local Medicine.-260 (65 per cent.) of the male informants in $E_{2}$ stated that they were personally responsible for preparing remedies for their families, whereas only $26(24 \cdot 5$ per cent.) of the women who were interviewed regarded this as one of their tasks.

Use of Native Medicines and Literacy.-Replies regarding the use of native medicines were analysed according to the level of literacy of the informants in $E_{2}$ (Table III); 47 people did not indicate their educational level reliably or merely announced that they were "self taught". When these are deducted and the remainder divided broadly into the two categories of 324 illiterate and 135 literate informants, there is no significant difference in their reported use of local remedies $\left(\chi^{2}=5.808\right.$; d.f. 2 ; $P<0.05)$.

TABLE III

REPORTED USE OF NATIVE MEDICINES IN E, DISTRICT BY LITERACY OF INFORMANTS

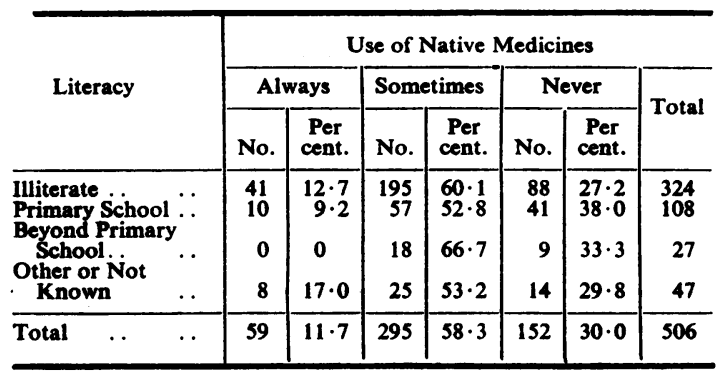

In Table IV the reported household usage of native medicines in the school children's families is related to the literacy of their fathers. Among the families where such medicines were in use "sometimes", there were five cases (two literate and three illiterate fathers) where they were said to be invariably employed. There is a significant difference in family practice according to father's literacy. $\left(\chi_{2}<6.889\right.$; d.f. $\left.1 ; \mathrm{P}<0.01\right)$.

TABLE IV

REPORTED USE OF NATIVE MEDICINES BY CHILDREN OF LITERATE AND ILLITERATE FATHERS (total 252*)

\begin{tabular}{|c|c|c|c|c|c|c|c|}
\hline \multirow{3}{*}{\multicolumn{2}{|c|}{$\begin{array}{c}\text { Father's } \\
\text { Educational } \\
\text { Level }\end{array}$}} & \multicolumn{6}{|c|}{ Family Use of Native Medicines } \\
\hline & & \multicolumn{2}{|c|}{ Never } & \multicolumn{2}{|c|}{ Sometimes } & \multicolumn{2}{|c|}{ Total } \\
\hline & & No. & Per cent. & No. & Per cent. & No. & Per cent. \\
\hline $\begin{array}{l}\text { Literate } \\
\text { Illiterate }\end{array}$ & $\therefore$ & $\begin{array}{l}67 \\
36\end{array}$ & $\begin{array}{l}48 \cdot 2 \\
31 \cdot 9\end{array}$ & $\begin{array}{l}72 \\
77\end{array}$ & $\begin{array}{l}51 \cdot 8 \\
68 \cdot 1\end{array}$ & $\begin{array}{l}139 \\
113\end{array}$ & $\begin{array}{l}100 \\
100\end{array}$ \\
\hline Total. . & .. & 103 & 40.9 & 149 & $59 \cdot 1$ & 252 & 100 \\
\hline
\end{tabular}

In thirty cases the father's literacy was not clearly indicated.

Table $\mathrm{V}$ shows that there was, furthermore, a highly significant relationship between the behaviour obtaining in the households of children whose mother had acquired some specialized professional training and those whose mothers were in unskilled occupations $\left(\chi_{2}=15.905\right.$; d.f. $\left.1 ; \mathrm{P}<0.001\right)$.

TABLE V

OCCUPATION OF MOTHERS OF 282 SCHOOL CHILDREN AND REPORTED HOUSEHOLD USE OF NATIVE MEDICINES

\begin{tabular}{|c|c|c|c|c|c|}
\hline \multirow{3}{*}{\multicolumn{2}{|c|}{$\begin{array}{l}\text { Household use of } \\
\text { Native Medicines }\end{array}$}} & \multicolumn{4}{|c|}{ Mother's Occupation } \\
\hline & & \multicolumn{2}{|c|}{ Skilled } & \multicolumn{2}{|c|}{ Unskilled } \\
\hline & & No. & Per cent. & No. & Per cent. \\
\hline $\begin{array}{l}\text { Sometimes } \\
\text { Never }\end{array}$ & $\begin{array}{l}. \\
\cdots\end{array}$ & $\begin{array}{l}17 \\
31\end{array}$ & $\begin{array}{l}35.4 \\
64.6\end{array}$ & $\begin{array}{r}155 \\
79\end{array}$ & $\begin{array}{l}66 \cdot 2 \\
33 \cdot 8\end{array}$ \\
\hline Total & $\cdots$ & 48 & $100 \cdot 0$ & 234 & $100 \cdot 0$ \\
\hline
\end{tabular}

Consultations with Native Healers.-51 per cent. of the families in the traditional area reported that members of their family had consulted native healers, whereas only 27 per cent. of the school children answered to this effect.

\section{Use OF Hospitals}

The information obtained demonstrated the very widespread use of modern medical institutions both by the people in $\mathrm{E}_{2}$ district and by the families of the secondary school children.

In the course of 506 interviews in the traditional area, only 47 people $(9 \cdot 3$ per cent.) averred that no-one in their family had ever visited hospital. Eleven of these were adherents of a faith-healing cult and four were themselves native doctors. 
Table VI illustrates the close correspondence in the reported use of hospitals by both groups studied.

TABLE VI

REPORTED FAMILY USE OF HOSPITALS BY TWO IBADAN GROUPS

\begin{tabular}{|c|c|c|c|c|c|}
\hline \multirow{2}{*}{\multicolumn{2}{|c|}{$\begin{array}{l}\text { Use of } \\
\text { Hospitals }\end{array}$}} & \multicolumn{2}{|c|}{$\begin{array}{l}\text { School Children's } \\
\text { Families }\end{array}$} & \multicolumn{2}{|c|}{$\underset{\text { Families }}{\mathbf{E}_{\mathbf{3}}}$} \\
\hline & & No. & Per cent. & No. & Per cent. \\
\hline $\begin{array}{l}\text { Sometimes : } \\
\text { Never }\end{array}$ & 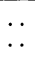 & $\begin{array}{r}263 \\
15\end{array}$ & $\begin{array}{r}94 \cdot 6 \\
5 \cdot 4\end{array}$ & $\begin{array}{r}459 \\
47\end{array}$ & $\begin{array}{r}90 \cdot 7 \\
9 \cdot 3\end{array}$ \\
\hline Total & $\cdots$ & $278^{*}$ & $100 \cdot 0$ & 506 & $100 \cdot 0$ \\
\hline
\end{tabular}

*Four children did not answer this question.

Adeoyo was the individual hospital with which the greatest number of families was familiar, but many households reported having had experience of both Adeoyo and University College Hospital.

Permission for Taking Children to Hospital.Contrary to opinions which have been expressed elsewhere (MacGregor, 1958) it appeared to be not invariably necessary for a mother to obtain her husband's permission to take a child to hospital. 51 of the women (48 per cent.) in $E_{2}$ declared that permission could be dispensed with and their opinion was upheld by 43 per cent. of the men. Some men even remarked that time should not be wasted over seeking permission. However, the majority of men did consider that it was proper for them to be previously consulted.

Opinions Regarding Hospitals and Home Therapy

Opinions among adults varied regarding the reputation of the two main hospitals for curing specific complaints. Some people challenged, "How should I know", or asserted, "Only the doctors know", whilst others were prepared to grant to either or both places a knowledge of universal cures. 20 per cent. volunteered the belief that University College Hospital was "for serious cases" and 16 per cent. specified that Adeoyo dealt with less serious conditions. Many had perceived a particular skill in the treatment of traumatic or surgical cases by hospitals in general.

On the other hand, there were some definite views about those conditions which ought preferably to receive home or traditional treatment. 97 people in $E_{2}$ quoted smallpox in this category and 26 indicated that mental illness could not be expected to benefit from the efforts of European doctors. "Giri", variously translated as convulsions or tetanus, was quoted by 88 adults as an example of an affliction requiring home care.

Eight warned of the special inadvisability of taking to hospital those whose illness was known to be due to witchcraft. Other complaints recommended for home care were impotence, barrenness, swollen testicles, gonorrhoea, and disorders of menstruation, all relating to the reproductive system of which the correct functioning is a matter of universal concern.

However, some old men deplored the loosening of their authority over the women in their compounds who, they complained, went off to Adeoyo hospital ante-natal clinics against the will or without the knowledge of the head of the household.

In answering the questionnaire, many people gave expression to opinions on illness and its cure which did not fit into any special category. For example, the sentiment was repeatedly voiced by adults that if it was one's fate to die no treatment, whether at home or in hospital, would be of any avail.

On a number of occasions an informant indicated that hospital treatment was used only as a last resort and that it was not really expected to succeed. Others explained that if hospital medicine proved useless it would be necessary for the patient to return home and use local remedies to effect a cure. One man, calling himself a Catholic, readily admitted to the use of every available kind of therapy, including prayer-healing and magic medicines.

Naturally, opinions were often influenced by individual experiences. Some reported the satisfactory cure of some specific infection, but others recalled only the uncivil treatment they had suffered from hospital employees which had determined them never again to submit to such indignities at the hands of strangers.

\section{Treatment of Specific Complaints}

The most noteworthy finding in response to this group of questions was that 251 people (nearly 50 per cent.) of all the households in the traditional area were in the habit of employing a particular native medicine as a prophylatic and treatment for fits or convulsions in children. The mixture, known as "agbo tutu", the cold medicine, is prepared at home in various ways, but the two basic ingredients are cow's urine and green tobacco leaves. The latter are steeped in the urine for at least 24 hours and the resulting liquid is kept readily available in a large pot. Poisoning from this cause is familiar to Ibadan paediatricians (Atalabi, 1964).

About 20 per cent. of the school children reported that native medicines, either alone or in conjunction with patent drugs, were used in their families for fits. On the other hand, European medicines have proved their worth against fevers, and common febrifuges, analgesics, and anti-malarials are widely known and used. But 35 per cent. of people in $E_{2}$ still treat fevers with their own herbal preparations and infusions. 
Whilst adults in $E_{2}$ were generally familiar with jaundice, only 40 per cent. of the school children knew of it. Many prescriptions for its cure were current in the traditional area.

Smallpox was the illness about which the people of Ibadan were most knowledgeable and fearful*. Numerous taboos are associated with this dreaded epidemic disease and sundry salves, soaps, and medicines were prescribed. There was widespread scepticism regarding the outcome of treatment in hospital, although it was realized that to hide smallpox cases at home was an offence.

\section{Discussion}

Until recently, circumstances in Africa have neither encouraged nor seemed to require investigation into community attitudes to hospitals and modern medical facilities. Faced with an apparently endless tide of patients, the over-worked doctor has had neither the time nor the inclination to consider even the reactions of his clients, far less the reservations of those who have chosen to stay at home. Consequently not many comparisons with other reported studies of this kind are possible.

However, Leighton, Lambo, Hughes, Leighton, Murphy, and Macklin (1963) engaged recently upon a survey of psychiatric illness amongst Yorubas in the Abeokuta area, 60 miles to the south of Ibadan, and asked their informants about recent purchases of native medicines. 35 to 44 per cent. of the people studied reported that they had bought such medicines in the course of the preceding year.

They surveyed 262 persons in Yoruba villages around the town of Abeokuta and 56 persons in Abeokuta itself. 82.5 per cent. of the men and 96 per cent. of the women from the villages were illiterate, but those in the small sample from Abeokuta town appear to have been better educated than the inhabitants of $\mathrm{E}_{\mathbf{2}}$ district in Ibadan, since 50 per cent. of the men and 17 per cent. of the women were said to be literate.

*During an epidemic in 1957 , out of 800 cases of smallpox in the Ibadan population, 160 were fatal.
Leighton's figures are compared in Table VII with those for the Ibadan group. The Table also includes the information given by Ioné Acquah (1958) regarding the literacy of a sample of 501 persons surveyed in Accra during 1955, who were better educated than any of the Nigerian groups; 93 per cent. of Ioné Acquah's informants declared that they sought only "scientific treatment" when ill, but she acknowledged that such answers might have been given to please the questioner.

Acquah had estimated that there were 274 native doctors in practice in Accra in 1955. In $E_{2}$ district of Ibadan, among 400 male informants, there were twelve native doctors, eight of them being over the age of 50 years. The subject of Ibadan native healers, herbalists, diviners, and others, and the preparation and sale of magic medicines have been discussed at length elsewhere (Maclean, 1964). Although the $E_{2}$ group was in no sense a random sample of the Ibadan population, having been deliberately selected from the most traditional part of town, there is reason to believe that the activities of native practitioners in the city of Ibadan to-day are not inconsiderable, and they are at present the subject of further study.

In the course of a demographic survey in connexion with the Lourenço Marques Cancer Survey, Flegg and Lutz (1959) posed questions regarding attitudes to medical treatment. They asked individuals whether they had ever personally been to hospital, either for in-patient or out-patient treatment, and also where they would go to seek treatment in the event of possible illness. Out of a sample of 1,367 males, only 232 (17 per cent.) had never been to hospital, and less than 0.5 per cent. confessed that they would consult the illegal "witchdoctors" for help in sickness. The authors pointed out that the latter finding could not, in the circumstances, be regarded as reliable.

At present a further attitude survey of this kind is being conducted in Bulawayo, based upon interviews with hospital patients (Flegg, 1965).

TABLE VII

COMPARISON OF THE EDUCATIONAL LEVEL OF INFORMANTS IN THREE WEST AFRICAN SURVEYS

\begin{tabular}{|c|c|c|c|c|c|c|c|c|c|c|c|c|c|c|c|c|c|c|}
\hline \multicolumn{3}{|c|}{ Place and Date } & \multicolumn{4}{|c|}{ Ibadan (1963) } & \multicolumn{4}{|c|}{ Yoruba Villages (1961) } & \multicolumn{4}{|c|}{ Abeokuta (1961) } & \multicolumn{4}{|c|}{ Accra (1955) } \\
\hline \multicolumn{2}{|c|}{ No. of Persons } & $\cdots$ & \multicolumn{4}{|c|}{506} & \multicolumn{4}{|c|}{262} & \multicolumn{4}{|c|}{56} & \multicolumn{4}{|c|}{501} \\
\hline \multirow[t]{2}{*}{ Sex } & \multirow[t]{2}{*}{. } & \multirow[t]{2}{*}{$\cdots$} & \multicolumn{2}{|c|}{ Male } & \multicolumn{2}{|c|}{ Female } & \multicolumn{2}{|c|}{ Male } & \multicolumn{2}{|c|}{ Female } & \multicolumn{2}{|c|}{ Male } & \multicolumn{2}{|c|}{ Female } & \multicolumn{2}{|c|}{ Male } & \multicolumn{2}{|c|}{ Female } \\
\hline & & & No. & $\begin{array}{c}\text { Per } \\
\text { cent. }\end{array}$ & No. & $\begin{array}{c}\text { Per } \\
\text { cent. }\end{array}$ & No. & $\begin{array}{l}\text { Per } \\
\text { cent. }\end{array}$ & No. & $\begin{array}{c}\text { Per } \\
\text { cent. }\end{array}$ & No. & $\begin{array}{c}\text { Per } \\
\text { cent. }\end{array}$ & No. & $\begin{array}{c}\text { Per } \\
\text { cent. }\end{array}$ & No. & $\begin{array}{c}\text { Per } \\
\text { cent. }\end{array}$ & No. & $\begin{array}{c}\text { Per } \\
\text { cent. }\end{array}$ \\
\hline \multirow[t]{2}{*}{$\begin{array}{l}\text { Educa- } \\
\text { tional } \\
\text { Level }\end{array}$} & $\begin{array}{l}\text { Illite } \\
\text { Liter } \\
\text { Not }\end{array}$ & $\begin{array}{l}\ldots \\
\dot{w}\end{array}$ & $\begin{array}{r}233 \\
130 \\
37\end{array}$ & $\begin{array}{r}58 \cdot 3 \\
32 \cdot 5 \\
9 \cdot 2\end{array}$ & $\begin{array}{r}91 \\
5 \\
10\end{array}$ & $\begin{array}{r}85 \cdot 9 \\
4 \cdot 7 \\
9 \cdot 4\end{array}$ & E & $\begin{array}{c}82 \cdot 5 \\
17 \cdot 5 \\
-\end{array}$ & - & $\begin{array}{r}96 \\
4 \\
-\end{array}$ & E & $\begin{array}{c}49 \cdot 5 \\
50 \cdot 5 \\
-\end{array}$ & E & $\begin{array}{l}83 \\
17 \\
-\end{array}$ & $\begin{array}{r}44 \\
281 \\
-\end{array}$ & $\begin{array}{l}13 \cdot 5 \\
86 \cdot 5 \\
-\end{array}$ & $\begin{array}{r}74 \\
102 \\
-\end{array}$ & $\begin{array}{l}42.0 \\
58.0 \\
-\end{array}$ \\
\hline & Tota & $\ldots$ & 400 & $100 \cdot 0$ & 106 & $100 \cdot 0$ & - & 100 & - & 100 & - & 100 & - & 100 & 325 & $100 \cdot 0$ & 176 & $100 \cdot 0$ \\
\hline
\end{tabular}


The Johannesburg Cancer Survey prompted an inquiry into the use of medical services by the Bantu population of one township (Higginson and Oettlé, 1960). This South African investigation revealed widespread confidence in the available Western medical facilities, although traditional doctors were still being consulted by 30 per cent. of people, often concurrently with Western practitioners.

The African surveys so far reported have not specifically considered the effect of age, sex, and literacy upon illness behaviour. The evidence from Ibadan confirms the experience elsewhere in Africa regarding the simultaneous recourse to traditional and modern medicine and indicates the persistence of the old practices, even among families who can afford secondary education for their children. In the poorer traditional areas of Ibadan, the exclusive use of native remedies is tending to become confined to the older inhabitants. The effect of literacy is less important in Old Ibadan than among those families whose economic status is higher.

The indication which this survey has afforded of the role played by women in altering habitual patterns of behaviour is of particular interest. In traditional society Yoruba women, although powerful in many spheres, seldom became recognized authorities on matters of health. Their role in the economy and use of native medicines has hitherto been mainly that of marketing to the patient those materials which the diviners and herbalists had prescribed. To-day it appears that Nigerian women who have had the benefit of higher education are playing an important part in banning the use of native remedies in their own households. Meanwhile, even in the traditional compounds, women are eager to take advantage of the available opportunities for ante-natal and paediatric care.

As far as the implications for the Cancer Incidence Survey are concerned, the present study would not appear to encourage over-confidence regarding the complete coverage of all cases of malignant disease by the hospital-based Registry. Not surprisingly, old people are still inclined to place their faith in traditional methods and it is precisely in the older age groups that cancer incidence rates in several African surveys have seemed unexpectedly low (Higginson and Oettlé, 1960; Davies, Wilson, and Knowelden, 1962; Prates and Torres, 1965; Edington and Maclean, 1965). It is tentatively suggested that, in Ibadan at least, the explanation may lie partially in the continued reliance by the elderly sector of the population upon traditional modes of treatment. Education, economic change, and experience are already gradually altering attitudes, but some considerable time will have to elapse before such influences affect the behaviour in illness of the majority of elderly members of the Ibadan community.

\section{SUMmaRY}

A health opinion survey was carried out from the Ibadan Cancer Registry in 1963 with a view to assessing the local population's acceptance of hospitals and the extent of their continued dependence upon traditional forms of treatment. Whilst local methods of healing were found to persist in varying degrees in all sections of the population, old people seemed most inclined to their exclusive use, whereas the wealthier, educated Nigerians and especially educated Nigerian women appeared to be effecting a break with tradition. The possible implications for the interpretation of cancer incidence rates in elderly Nigerians are considered.

The study reported here was carried out with the aid of a grant from the British Empire Cancer Campaign and with the encouragement of Prof. G. M. Edington of the Department of Pathology, University of Ibadan.

\section{REFERENCES}

Acquah, Ioné (1958). "Accra Survey". University of London Press, London.

Atalabi, Gbadua (1964). "Cow's Urine" Poisoning, Dokita, 6, 1 .

Davies, J. N. P., Wilson, B. A., and Knowelden, J. (1962). Lancet, $2,328$.

Edington, G. M., and Maclean, C. M. U. (1965). "Report on the Ibadan Cancer Survey" (in press).

Flegg (or Mitchell), H. (1965). Personal communication.

Flegg, H., and Lutz, W. (1959). J. soc. Res., 10.

Higginson, J., and Oettlé, A. G. (1960). J. nat. Canc. Inst., $24,589$.

Leighton, A. H., Lambo, T. A., Hughes, C. G., Leighton, D. C., Murphy, J. M., and Macklin, D. B. (1963). "Psychiatric Disorder among the Yoruba". Cornell University Press, Ithaca, New York.

Lloyd, P. C. (1960). "Yoruba Towns", Ibadan, 9, 26.

MacGregor, M. (1958). Arch. Dis. Childh., 33, 277.

Maclean, C. M. U. (1964). "Attitudes and Beliefs relating to Health and Disease in an Urban West African Community." Dissertation for Diploma in Public Health, University of Edinburgh.

Prates, M. D., and Torres, F. O. (1965). “A Cancer Survey in Lourenço Marques." (in press). 